$\begin{array}{r}\text { Progressive Physics Journal } \\ \text { Volume 2, Nomor 1, Juni } 2021 \\ \text { ISSN 2722-7707 (online) } \\ \text { http://jurnal.fmipa.unmul.ac.id/index.php/ppj/index } \\ \hline\end{array}$

\title{
Pembuatan dan Karakterisasi Rochelle Salt Crystal
}

\author{
M. Wafieq Akbar Al Asyrafi $i^{(1, *)}$, Adrianus Inu Natalisanto ${ }^{1}$, Rahmat Gunawan ${ }^{2}$ \\ 1)Jurusan Fisika, Fakultas MIPA, Universitas Mulawarman \\ 2) Jurusan Kimia, Fakultas MIPA, Universitas Mulawarman
}

*E-mail : wwafiqakbar@gmail.com

\begin{abstract}
Rochelle Salt is the first synthesis Crystal made by Pierre Siegnette La Rocchelle in France. Rochelle Salt has several characteriztion, one of characterization is piezoelectric effect where the crystal can change the kinetic energy to electrical energy. Nowaday, piezoelectric effect plays the role in advancing the rewenable source energy. Rochelle Salt can be created using tartar cream and washing soda reacted with distilled water as a solvent. The solution was reacting until there was no more reaction or supersaturation condition. In the crystalization process, the solution waited for 2 days until the crystal seed appeared. The crystal growth process was using the method of growing crystal in solution for 1 month until the crystal bigger enough for research to dicovered the piezoelectric effect. Based on the result that have been obtained, Rochelle Salt had piezoelectric effect. In the analysis process, crystal was hit using wooden hitter and metal hitter, the voltage was increase when the crystal is hit by hitter. The piezoelectric effect in crystal also disappeared toward time.
\end{abstract}

Keywords : Crystal Creation, Crystal Growth, Piezoelectric effect, Rochelle Salt

\section{PENDAHULUAN}

\section{Latar Belakang}

Energi merupakan salah satu faktor penting dalam menunjang kehidupan dan aktivitas masyarakat. Dalam keseharian, saat ini energi yang digunakan merupakan energi yang berasal dari energi tak terbarukan (non renewnable source energy) seperti batu bara, minyak bumi dan gas alam. Namun, apabila sumber energi tersebut terus digunakan, maka sumber energi tersebut akan habis. Sehingga untuk mencegah hal tersebut, maka pemanfaatan energi alternatif dapat dijadikan solusi. Solusi untuk mencegah habis sumber energi tak terbarukan dengan mengembangkan sumber energi alternatif berasal dari sumber energi terbarukan (renewable source) yang saat ini ilmuan berlomba untuk mengembang sumber tersebut agar dapat digunakan secara optimal.

Menurut penelitian [1], salah satu sumber energi alternatif cukup menjadi sorotan dalam dekade terakhir ialah pengumpulan energi piezoelektrik atau piezoelectric harvesting energy. Hal ini Karena kelebihannya dalam kepadatan daya tampung tinggi, kesederhanaan model dan skalabilitasnya. Selain itu, piezoelektrik dapat menkonversi energi mekanik menjadi energi elektrik. 
Menurut penelitian [2], salah satu sumber energi piezoelektrik tersebut yang cukup dikenal adalah Rochelle Salt. Rochelle Salt pertama kali disintesis oleh Pierre Siegnette La Rocchelle di Perancis. Salah satu karakteristik dari Rochelle Salt adalah kristal Rochelle Salt memiliki fenomena efek piezoelektrik langsung dengan menganalisisnya melalui percobaan ketukan. Selain salah satu material yang bersifat piezoelektrik Rochelle Salt tidak mengandung unsur langka dalam komposisinya mudah didapat di alam dan dapat sintesis dalam laboratorium dan memiliki kompabilitas lingkungan yang baik.

Menurut penelitian [3], Rochelle Salt merupakan contoh material piezoelektrik yang sederhana setelah kuarsa. Hal ini dapat dibuktikan dengan menggunakan teknik sistem tiga elektroda untuk konstanta elastis dan piezoelektrik pada kristal. Teknik ini digunakan pula untuk transisi pada kristal pada suhu $24^{\circ} \mathrm{C}$. Hasilnya terbukti bahwa kristal Rochelle Salt adalah material piezoelektrik dengan adanya peningkatan sinyal keluaran pada kristal dan ditemukan redaman mekanis pada kristal Rochelle Salt.

Penelitian ini bertujuan untuk membuat dan menganalisis karakteristik dari Rochelle Salt, mengetahui proses pembuatan kristal tersebut menggunakan bahan dapur yaitu krim tartar dan soda cuci, analisis karakteristik tersebut dilakukan melalui pencarian voltase listrik yang ditimbulkan oleh kristal. Peneliti ingin memberikan pengetahuan kepada pembaca tentang Rochelle Salt Crystal.

\section{TINJAUAN PUSTAKA}

\section{Pembuatan dan Pertumbuhan Kristal}

Dalam pembuatan kristal, terdapat beberapa metode yang dapat digunakan. Secara umum, teknik pembuatannya sama, yaitu mereaksikan antara bahan dasar kristal dengan melakukan proses perubahan-perubahan suhu secara optimal. Dalam pembuatannya, untuk mendapatkan larutan supersaturasi atau larutan jenuh dilakukan dengan beberapa metode, yaitu metode pendinginan. Metode yang sering digunakan adalah metode penguapan. Untuk mendapatkan kejenuhan larutan, saat pelarut menguap dari larutan dapat meningkatkan konsentrasi dari larutan. Apabila penguapan berakhir dengan suhu konstan larutan menjadi jenuh, maka setelah kejenuhan pada titik maksimal maka larutan akan memulai proses kristalisasi $[4,5]$.

Pertumbuhan kristal adalah proses pembentukan molekul-molekul yang telah terbentuk setelah proses reaksi kimia. Proses pertumbuhan kristal tentunya melibatkan yang melibatkan zat padat, cair dan gas. Untuk proses pertumbuhan kristal dalam penelitian ini dilakukan dengan menggunakan metode pertumbuhan di dalam larutan. Dengan kata lain terdapat empat langkah setelah kejenuhan larutan didapat, yaitu, pendidihan larutan selama reaksi berlangsung, penguapan larutan, pengubahan konsentrasi larutan dan pendinginan larutan secara perlahan $[4,6]$.

\section{Rochelle Salt}

Rochelle Salt atau bisa disebut dengan Garam Rochelle merupakan senyawa kimia dari hasil reaksi krim tartar (Potasium Bitatrate) dan soda cuci (Sodium Carbonate) dapat dilihat dari reaksi berikut:

$$
\mathrm{KC}_{4} \mathrm{H}_{5} \mathrm{O}_{6}+\mathrm{Na}_{2} \mathrm{Co}_{3} \rightarrow \mathrm{KNaC}_{4} \mathrm{H}_{4} \mathrm{O}_{6}+\mathrm{Co}_{2}+\mathrm{H}_{2} \mathrm{O}
$$

Potasium sodium tartrate tetrahydrate atau $\mathrm{KNaC}_{4} \mathrm{H}_{4} \mathrm{O}_{6} .4 \mathrm{H}_{2} \mathrm{O}$ bisa disebut garam Rochelle atau garam Siegnette salah satu material yang memiliki sifat piezoelektrik [7]. 


\section{Piezoelektrik}

Piezoelektrik atau piezoelektrisitas difenisikan sebagai kemampuan suaru material yang dapat menghasilkan polarisasi elektrik jika mendapatkan perlakukan tekanan. Efek ini merupakan konversi dari energi mekanik menjadi energi elektrik atau sebaliknya. Fenomena Piezoelektrik pertama kali ditemukan oleh Curie bersaudara, Pierre Curie (1859 - 1906) dan Jacques Curie (1855 - 1941). Pada tahun 1880, mereka menemukan sebagian kristal ketika diberi tekanan ke arah tertentu tampak voltase positif dan negatif pada beberapa bagian permukaan kristal. Voltase ini terjadi pada saat kristal ditekan dan hilang pada saat kristal tidak ditekan $[8,9]$.

Piezoelektrik adalah interaksi linier antara sistem mekanik dan sistem elektrik didalam kristal non-centric. Efek piezoelektrik didefinisikan sebagai perubahan polarisasi listrik sebanding dengan voltase dimana material akan menimbulkan pemindahan dielektrik didalam material tersebut. Efek piezoelektrik sangat bergantung pada bentuk kesimetrisan dari kristal. Apabila kristal yang termasuk sebelas kelompok titik yang memiliki simetris pusat tidak dapat menghasilkan efek piezoelektrik [10].

Berdasarkan dari Gambar 1 skema efek piezoelektrik langsung terjadi. Material piezoelektrik diberi energi mekanik berupa tekanan atau regangan sehingga material menghasilkan energi elektrik dapat berupa rapat muatan permukaan, medan listrik atau voltase. Banyak kegunaan piezoelektrik langsung saat ini. Selain efekpiezoelektrik langsung, terdapat pula efek kebalikannya atau converse piezoelectric, yakni menngonversi energi elektrik menjadi energi mekanik [11].

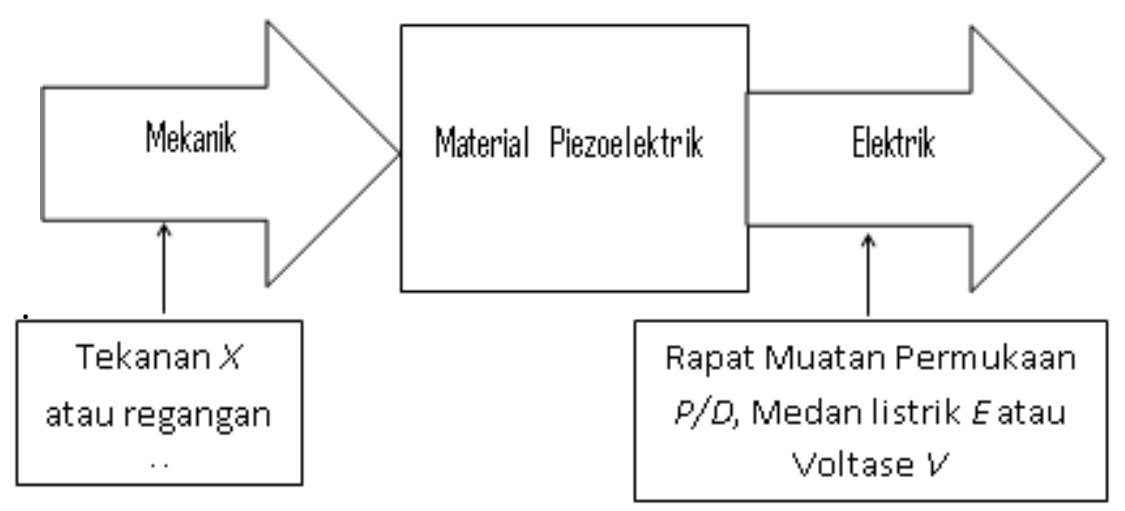

Gambar 1. Skema Efek Piezoelektrik Langsung 


\section{METODE PENELITIAN}

\section{Waktu dan Tempat}

Penelitian ini dilaksanakan mulai September 2019 hingga April 2020 di Laboratorium Elektronika dan Instrumentasi, Fakultas Matematika dan Ilmu Pengetahuan Alam, Unversitas Mulawarman, Samarinda.

\section{Alat dan Bahan}

Alat yang digunakan dalam penelitian ini adalah gelas reaksi $(80 \mathrm{ml})$ sebagai wadah kristalisasi, kompor sebagai pemanas, gelas pyrex $(700 \mathrm{ml})$ sebagai wadah reaksi bahan-bahan termometer sebagai pengukur suhu untuk menjaga suhu optimal larutan, wajan, osiloskop sebagai alat analisis voltase keluaran dari kristal, pemukul kayu, pemukul besi serta peralatan pendukung lain seperti sendok, gunting, pensil, penggaris, neraca dan stopwatch.

Bahan-bahan yang digunakan dalam penelitian ini adalah krim tartar, soda cuci sebagai bahan utama, aquades sebagai pelarut, kertas saring untuk menyaring larutan, air sebagai media pemanas antara wajan dan gelas pyrex dalam proses reaksi dan benang nilon sebagai bahan bantu untuk pertumbuhan kristal.

\section{Prosedur Penelitian}

Pembuatan kristal Rochelle Salt pada penelitian ini menggunakan bahan-bahan, yaitu krim tartar (potassium bitartrat) dan soda cuci (sodium carbonate) sebagai bahan terlarut, serta aquades atau $\mathrm{H}_{2} \mathrm{O}$ murni sebagai pelarut. Proses pembuatan kristal dilakukan dengan menyiapkan aquades sebanyak $250 \mathrm{ml}$ di dalam gelas pyrex, lalu dituangkan 250 gram krim tartar ke dalam gelas pyrex dan diaduk hingga krim tartar larut dalam aquades. Setelah itu, disiapkan wajan berisi air, kemudian dipanasi di atas kompor. Setelah itu, gelas pyrex yang berisi krim tartar terlarut diletakkan ke wajan yang berisi air, dengan kata lain krim tartar terlarut dijaga supaya tidak tercampur dengan air di wajan.

Setelah larutan krim tartar dalam gelas pyrex bersuhu $70^{\circ} \mathrm{C}$ atau lebih, soda cuci dimasukkan ke dalam larutan sedikit demi sedikit, di mana pada proses ini timbul reaksi antara krim tartar dengan soda cuci yang ditandai dengan adanya gelembung-gelembung pada larutan. Setelah gelembung-gelembung hilang, soda cuci dituangkan lagi sedikit demi sedikit, begitu seterusnya sampai larutan dalam gelas pyrex jenuh (tidak bereaksi lagi atau supersaturasi), dengan kata lain hal ini ditandai oleh larutan yang tidak menghasilkan gelembung. Pada tahap ini, larutan menjadi larutan Rochelle Salt.

Selanjutnya, larutan Rochelle Salt disaring dengan menggunakan kertas saring untuk menyaring endapan-endapan yang tidak dikehendaki. Lalu, larutan Rochelle Salt hasil saringan dituangkan ke dalam gelas reaksi untuk didinginkan secara perlahan-lahan sehingga suhu larutan Rochelle Salt sama dengan suhu ruang. Pada saat larutan telah mencapai suhu ruang, larutan didiamkan selama 2 hari hingga terbentuk benih-benih kristal di dasar gelas reaksi dan larutan disaring kembali dengan menggunakan kertas saring, di mana hal ini bertujuan untuk memisahkan larutan dengan benih-benih kristal agar mudah mengambil benih tersebut.

Setelah mendapat benih kristal, benih kristal yang terpilih diletakkan kembali ke dalam larutan yang telah disaring lalu menunggu selama 2 bulan untuk mendapatkan ukuran kristal yang cukup besar untuk diteliti. Untuk prosedur analisis data piezoelektrik dilakukan untuk mencari voltase keluaran yang dihasilkan oleh kristal dengan menggunakan osiloskop sebagai alat pengukur voltase keluaran. Prosedur awal analisis dilakukan dengan meletakkan krtistal yang dihubungkan ke osiloskop serta menyiapkan stopwatch. Lalu menyiapkan pemukul kayu dan mengamati voltase awal pada kristal sebelum memukul kristal. Lalu, kristal dipukul dan 
mengamati perubahan voltase pada kristal ketika terpukul. Lalu, mengulangi langkah sebelum dengan menggunakan pemukul besi.

Tabel 1. Rancangan Tabel Analisis Data

Voltase (V) Durasi (s)

\section{HASIL DAN PEMBAHASAN}

\section{Hasil dan Verifikasi Kristal}

Dari prosedur-prosedur yang telah dilakukan, didapatkan kristal yang berukuran cukup besar dalam proses pertumbuhan kristal sebelumnya. Peneliti menggunakan benang nilon yang berfungsi untuk mengantung kristal didalam larutannya. Hal ini bertujuan untuk mendapatkan bentuk kristal yang berupa monokristal. Namun, bentuk kristal yang didapatkan tidak berupa monokristal, melainkan berbetuk polikristal sebagaimana diperlihatkan pada Gambar 2.

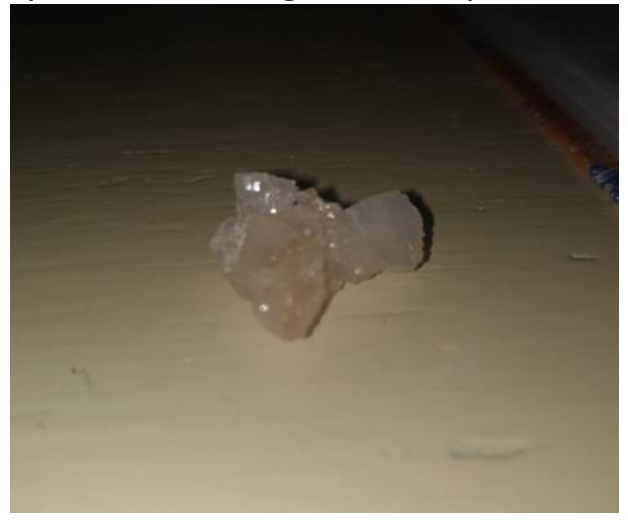

\section{Gambar 2. Bongkahan Kristal Rochelle Salt}

Verifikasi dan karakterisasi hasil pembuatan kristal Rochelle Salt ini dilakukan di Laboratorium Kimia Institut Teknologi Bandung dengan menggunakan Scanning Electron Microscope (SEM). Hasil yang telah didapat melalui SEM, didapat struktur morfologi atau citra permukaan kristal dengan perbesaran 5000 kali dan berbentuk runcung tak beraturan bertumpuk anatara satu dan lainnya dapat dilihat pada Gambar 3.

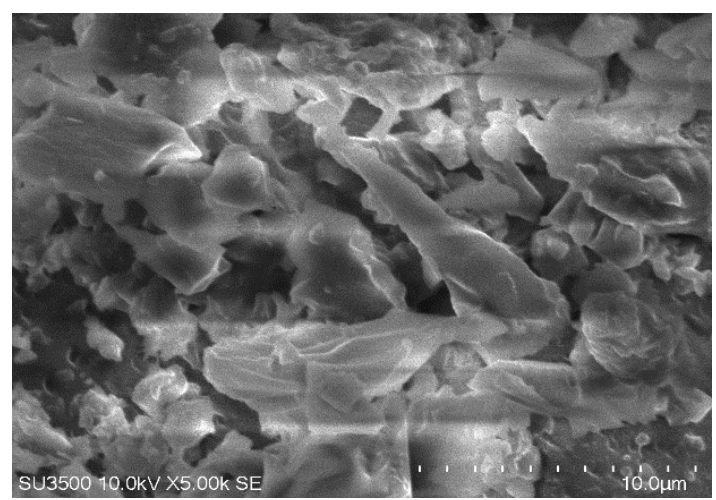

Gambar 3. Morfologi dari Rochelle Salt 


\section{Analisis Data Piezolektrik pada Kristal}

Pengambilan data piezoelektrik didapatkan dengan dipukulnya kristal Rochelle Salt dan digunakan osiloskop untuk mengukur voltase keluaran kristal terhadap waktu. Pengambilan data dilakukan sebanyak dua tahap, dengan varian pemukul kristal berupa pemukul kayu dan pemukul besi. Diperlihatkan pada Tabel 2 dan Tabel 3 merupakan hasil dapat yang didapat dengan keterangan $V_{i}$ adalah voltase awal, $V_{p}$ adalah voltase puncak, $t_{1}$ adalah waktu efek piezoelektrik dan $a$ adalah kenaikan voltase ketika terpukulnya kristal.

Tabel 2 Hasil Data dengan Pemukul Kayu

\begin{tabular}{|c|c|c|c|c|c|c|}
\hline No & waktu (s) & volt $(\mathrm{V})$ & $V_{i}(\mathrm{~V})$ & $V_{p}(\mathrm{~V})$ & $t_{1}(\mathrm{~s})$ & $a(\mathrm{~V})$ \\
\hline \multirow{4}{*}{1} & 0.88 & 0.95 & \multirow{4}{*}{0.31} & \multirow{4}{*}{0.95} & \multirow{4}{*}{3.54} & \multirow{4}{*}{0.35} \\
\hline & 1.77 & 0.47 & & & & \\
\hline & 2.65 & 0.42 & & & & \\
\hline & 3.54 & 0.35 & & & & \\
\hline \multirow{4}{*}{2} & 0.73 & 1.24 & \multirow{4}{*}{0.28} & \multirow{4}{*}{1.24} & \multirow{4}{*}{2.94} & \multirow{4}{*}{0.54} \\
\hline & 1.47 & 0.35 & & & & \\
\hline & 2.205 & 0.34 & & & & \\
\hline & 2.94 & 0.33 & & & & \\
\hline \multirow{4}{*}{3} & 0.95 & 0.67 & \multirow{4}{*}{0.29} & \multirow{4}{*}{0.67} & \multirow{4}{*}{3.82} & \multirow{4}{*}{0.22} \\
\hline & 1.91 & 0.43 & & & & \\
\hline & 2.86 & 0.35 & & & & \\
\hline & 3.82 & 0.36 & & & & \\
\hline
\end{tabular}

Berdasarkan Tabel 2, nilai waktu di analisis regresi terhadap volt hingga didapat grafik sebagai berikut:

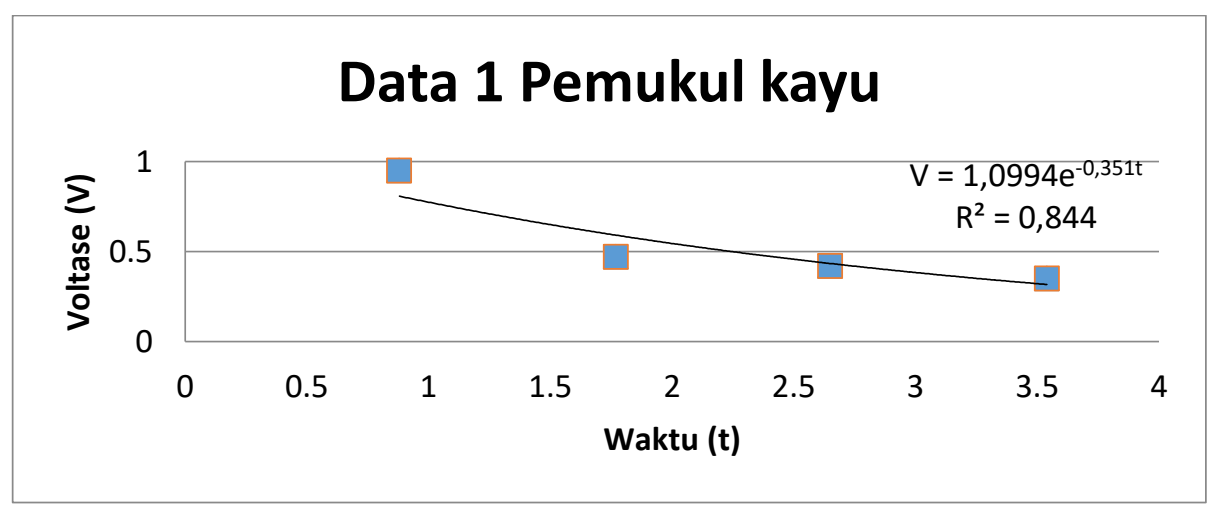

(a)

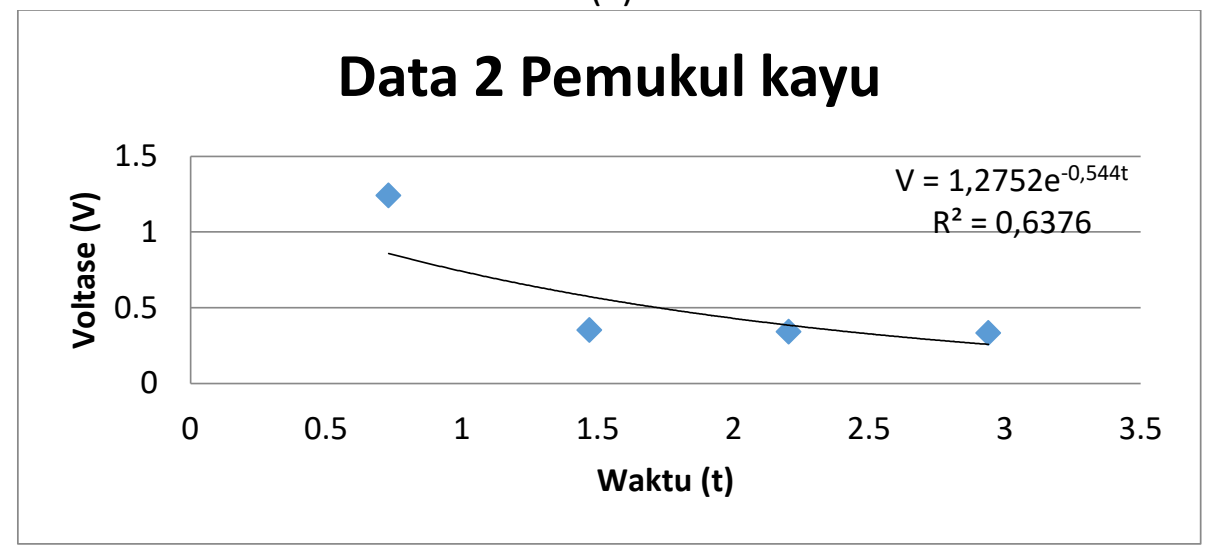

(b) 


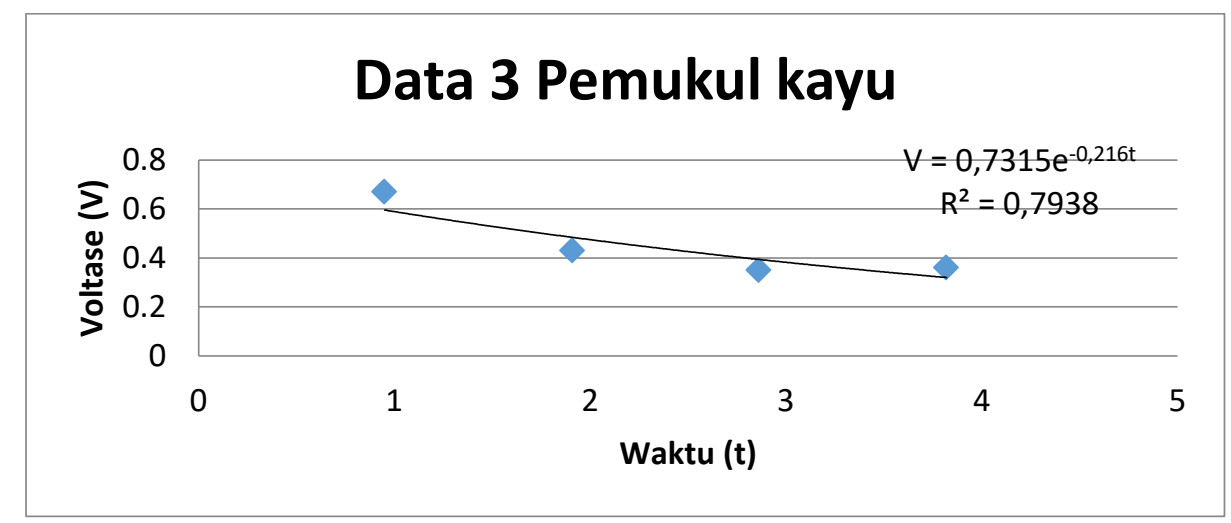

(c)

Gambar 4. Grafik Data Pemukul Kayu: (a) Data 1 (b) Data 2 (c) Data 3

Tabel 3. Hasil Data dengan Pemukul Besi

\begin{tabular}{ccccccc}
\hline No & waktu (s) & volt (V) & $V_{i}(\mathrm{~V})$ & $V_{p}(\mathrm{~V})$ & $t_{1}(\mathrm{~s})$ & $a(\mathrm{~V})$ \\
\hline \multirow{4}{*}{1} & 0.58 & 1.06 & & & & \\
& 1.17 & 0.54 & & & & \\
& 1.75 & 0.33 & 0.30 & 1.06 & 2.93 & \\
& 2.34 & 0.31 & & & & \\
& 2.93 & 0.30 & & & & \\
& 0.59 & 4.12 & & & & \\
2 & 1.19 & 0.37 & & & & \\
& 1.79 & 0.29 & 0.30 & 4.12 & & \\
& 2.39 & 0.28 & & & & \\
& 2.99 & 0.27 & & & & \\
& 0.78 & 0.51 & & & & \\
& 1.56 & 0.43 & & & & \\
& 2.34 & 0.35 & 0.29 & 0.51 & & \\
& 3.12 & 0.33 & & & & \\
& 3.91 & 0.31 & & & & \\
\end{tabular}

Berdasarkan Tabel 3, nilai waktu di analisis regresi terhadap volt hingga didapat grafik sebagai berikut:

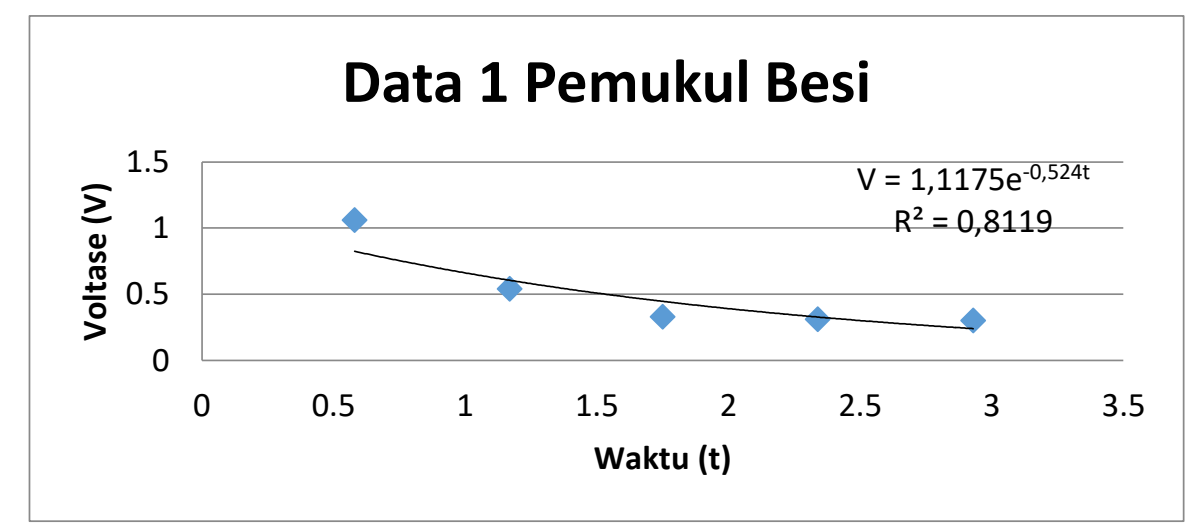

(a) 


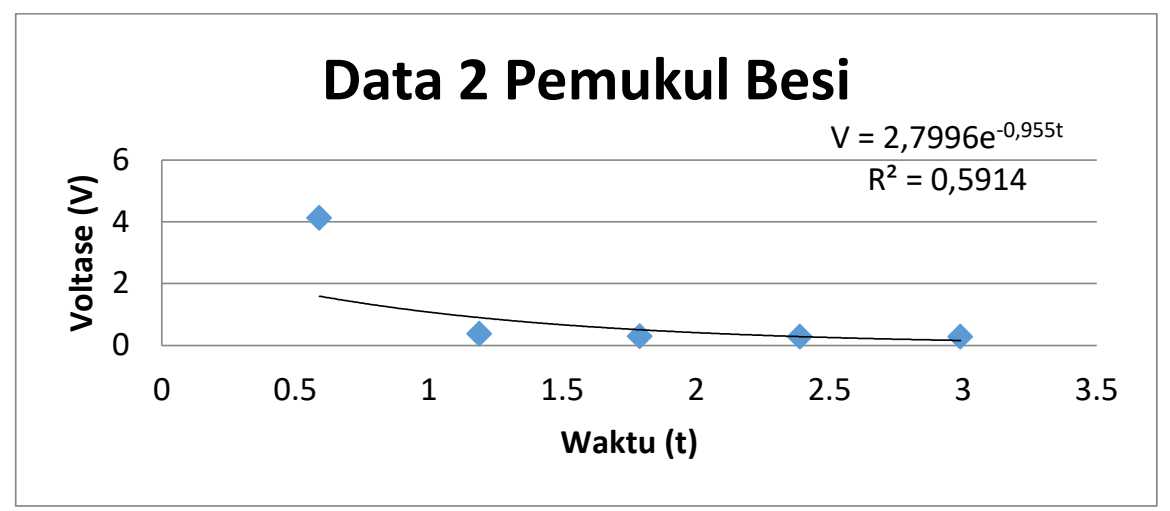

(b)

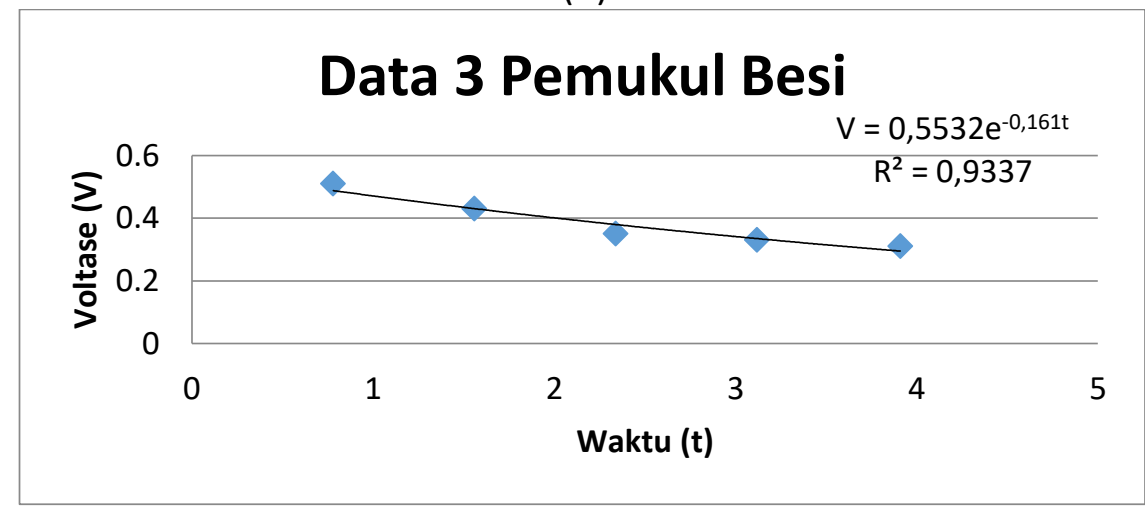

(c)

Gambar 5. Grafik Data Pemukul Besi: (a) Data 1 (b) Data 2 (c) Data 3

Berdasarkan dari Tabel 2, Tabel 3, Gambar 4, dan Gambar 5, dapat diketahui nilai-nilai voltase puncak $\left(V_{p}\right)$, voltase awal $\left(V_{i}\right)$, waktu efek piezoelektrik $\left(t_{1}\right)$ dan kenaikan voltase (a) untuk mencari nilai waktu awal mulainya efek piezoelektrik $\left(t_{0}\right)$ untuk mendapatkan nilainya dilakukan perhitungan analisis regresi eksponensial dan didapat hasil yang dapat dilihat pada Tabel 4.

Tabel 4 Nilai Waktu Awal $\left(t_{0}\right)$ Piezoelektrik

\begin{tabular}{ccc}
\hline No & Pemukul Kayu (sekon) & Pemukul Besi (sekon) \\
\hline 1 & 0.349 & 0.521 \\
2 & 0.201 & 0.246 \\
3 & -0.0568 & 0.403 \\
\hline
\end{tabular}

\section{Pembahasan}

Efek piezoelektrik dari kristal Rochelle Salt terjadi karena adanya resonansi konjugasi atau mesomerisme pada molekul kristal. Timbulnya listrik pada kristal disebabkan adanya perpindahan elektron. Timbulnya energi elektrik karena ikatan ionik lemah atau ikatan ionik yang berkarakter kovalen pada molekul Rochelle Salt.

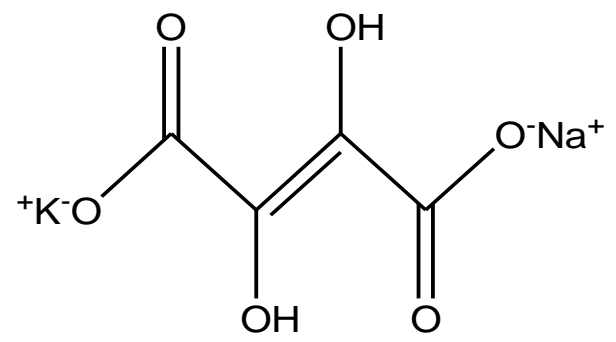

Gambar 6. Rochelle Salt Sebelum Adanya Gerak Elektron 
Gaya yang diberikan pada Kristal pada Rochelle Salt membuat lepasnya Ion Kalium $\left(\mathrm{K}^{+}\right)$dan Natrium $\left(\mathrm{Na}^{+}\right)$molekul Rochelle Salt pun menjadi tidak stabil.

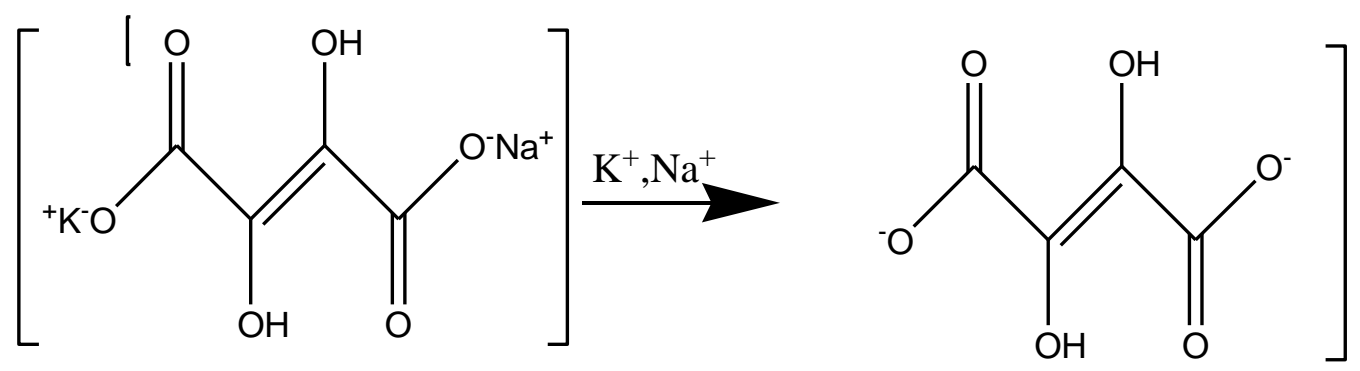

Gambar 7. Lepasnya Ion $\mathrm{K}^{+}$dan $\mathrm{Na}^{+}$Molekul Rochelle Salt Tidak Stabil

Dengan tidak stabilnya molekul Rochelle Salt seperti yang ditunjukkan pada Gambar 7, mengubah ikatan karbon Rochelle Salt tersebut. Hal ini menyebabkan adanya resonansi konjugasi atau mesomerisme dapat dilihat pada Gambar 8.

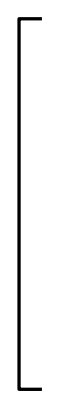<smiles>CC(C(=O)[O-])=C(O)C(=O)[O-]</smiles>
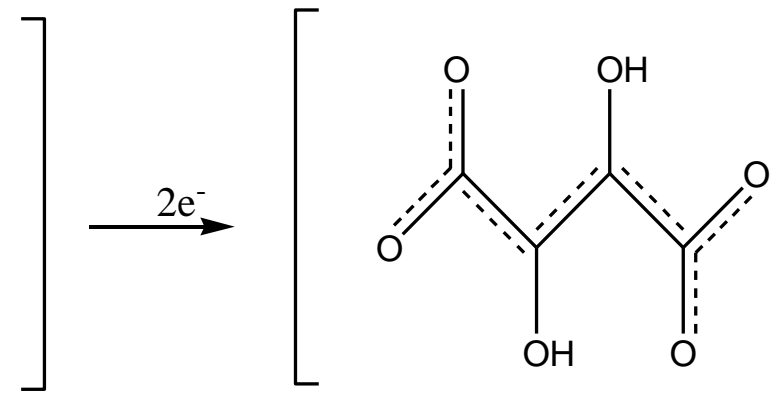

Gambar 8. Molekul Rochelle Salt pada saat Melepaskan Elektron

Pada saat terjadinya resonansi konjugasi inilah Rochelle Salt melepaskan elektron sehingga kristal pun menimbulkan voltase listrik. Elektron yang mengalir dan voltase awal $\left(V_{i}\right)$ meningkat menjadi voltase puncak $\left(V_{p}\right)$ dalam selang waktu beberapa sekon $\left(t_{1}\right)$. Dari data yang telah didapat, kristal Rochelle Salt mengeluarkan voltase ketika kristal terpukul oleh pemukul. Seiring berjalannya waktu, voltase pada kristal menurun hingga kembali ke keadaan semula sebelum kristal terpukul. Hal ini menunjukkan bahwa kristal Rochelle Salt memiliki efek piezoelektrik langsung, yakni energi kinetik pemukul teralih menjadi energi kinetik elektron material sehingga material tersebut akan menghasilkan voltase. Dari grafik-grafik yang telah ditampilkan dapat dilihat bahwa voltase memiliki hubungan terhadap waktu efek piezoelektrik memiliki jangka waktu terbatas dan singkat. Setelah kristal terpukul efek piezoelektrik pun memudar dan kembali ke keadaan semula. Adanya listrik tentunya ada perpindahan elektron.

Data yang telah didapat terdapat dua jenis pemukul yang digunakan untuk memukul kristal, yaitu pemukul berbahan kayu dan pemukul berbahan besi. Hasil data dari pemukul kayu cenderung didapatkan nilai voltase puncak $\left(V_{p}\right)$ lebih kecil dibandingkan dengan pemukul berbahan besi. Untuk mengetahui perbedaaan hasil data antara pemukul kayu bersifat isolator dan pemukul besi yang bersifat konduktor sehingga ada pengaruh perpindahan elektron dari pemukul ke kristal. Dari data yang telah didapat tidak mengikuti sesuai teori, yaitu dengan tidak melibatkan pengukuran tekanan dalam pencarian efek piezoelektrik. Dalam penelitian ini hanya mencari korelasi dari fenomena efek piezoelektrik tersebut dengan metode analisis regresi dari keluaran voltase terhadap waktu.

Dari hasil data yang telah didapat, ada beberapa data yang hanya memiliki dua nilai voltase dan beberapa yang memiliki lebih dari dua voltase yang didapat. Hal ini terjadi karena ketika kristal terpukul ada pengaruh polarisasi spontan dalam kristal dan tentunya ada unsur 
human error. Dalam mengukur waktu dengan voltase hingga mendapat analisis nilai t0 negatif. Nilai negatif tersebut disebabkan karena pencatatan waktu terlalu lambat sehingga terjadi kesalahan sistematis dalam pengukurannya sehingga bernilai negatif. Dengan dua nilai voltase yang didapat korelasi $\left(R^{2}\right)$ mencapai mencapai nilai 1 . Namun, dari beberapa data yang lain didapat korelasi $\left(R^{2}\right)$ melebihi nilai 0.5 yang artinya nilai voltase memiliki hubungan cukup kuat terhadap waktu.

\section{KESIMPULAN}

Rochelle Salt dapat dibuat dengan bahan berupa krim tar-tar dan soda cuci direaksikan dengan aquades dengan suhu pelarut diatas $70^{\circ} \mathrm{C}$ hingga jenuh. Pertumbuhan kristal garam Rochelle dilakukan dengan teknik pertumbuhan kristal, yaitu pertumbuhan kristal didalam larutan Rochelle Salt yang telah direaksikan seiring berjalannya waktu larutan menguap kristal pun semakin tumbuh. Karakteristik secara fisis dari kristal Rochelle Salt yang didapat yaitu, kristal Rochelle Salt yang berbentuk polikristal. Kristal sangat mudah dihancurkan, dapat dilarutkan dan direkristalisasi di dalam pelarut bersuhu di atas $70^{\circ} \mathrm{C}$. Kristal menghasilkan voltase listrik apabila diberikan gaya. Hal ini membuktikan bahwa karakteristik Rochelle Salt lainnya yaitu, memiliki fenomena efek piezoelektrik dengan kata lain merupakan efek Piezoelektrik langsung. Kenaikan voltase listrik naik terjadi ketika kristal dipukulmenggunakan pemukul menimbulkan efek piezoelektrik. Namun efek piezoelektrik pun memudar seiring berjalannya waktu.

\section{UCAPAN TERIMA KASIH}

1. Bapak Suhadi Muliyono, M.Si selaku dosen penguji I dan Bapak Ahmad Zarkasi, M.Si selaku dosen penguji II yang telah memberi masukan demi penyempurnaan penulisan penelitian ini.

2. Kepala Laboratorium Elektronika dan Instrumentasi atas segala fasilitas yang dapat digunakan saat penelitian.

\section{DAFTAR PUSTAKA}

[1]. Toprak, A., \& Tigli, O. 2014. "Piezoelectric Energy Harvesting: State-of-the art and challenges". Applied Physic Review, 1(3).

[2]. Lemaire, E., Moser, R.,Borsa, C.J., Shea, H. \& Briand, D. 2015. “Green paper-based piezoelectric material for sensors and actuator". Procedia Engineering, 120, 360-361.

[3]. Pereira, D. P., Nero, J. D., Moreira, M. D., de Oliveira, P. C., Alcantara, P., Remédios, C. M. R., \& Moreira, S. G. C. 2017. 'Theoretical and Experimental Features of Nano-Crystals Rochelle Salt: Piezoelectric Resonance and Phase Transition. Journal of Nanoscience and Nanotechnology', 17(6). 4180-4184

[4]. Myerson, Allan S. 2002. "Handbook of Indrustrial Crystallization". USA: ButterworthHeinemann

[5]. Mullins, J. W. 2001. "Crystallization Fourth Edition". Oxford, UK. Butterworth-Heinemann.

[6]. Dudley, Michael, Dhanaraj, Govindhan, Byrappa, Kullaiah, Prasad, Vishwanath. 2010. "Handbook of Crystal Growth". Berlin: Springer Heidelberg Dordrecht.

[7]. Buchanan, John P. 1956. "Handbook of Piezoelectric Crystal for Radio Equipment Designers". Ohio, USA. Phileo Coporation.

[8]. Yulianti, Evi. Triwahyuni, Dona. Ahda, Syahfandi. \& Deswita. 2012. "Pembuatan Bahan Piezoelektrik Ramah Lingkungan $\mathrm{BiNaTiO}_{3}$ dengan Metode Molten Salt". Jurnal Sains Indonesia. Vol.14, Oktober 2012, hal 13-17. 
[9]. Harriyanto, Agus R., Utomo. 2013. "Studi Analisis Gelombang Tegangan Piezoelektrik". Depok, Indonesia. Departemen Teknik Elektro Universitas Indonesia.

[10]. Tichy, Jan. 2010. "Fundamental of Piezoelectric Sensorics". Berlin. Springer Heidelberg Dordrecht.

[11]. Vijaya, MS. 2013. "Piezoelectric Material and Device". Boca Raton, USA. CRC Press. 